\title{
Original article (full paper) \\ The impact of the global economic crisis on the finances of non-governmental sport organizations in Slovenia remains to be seen
}

\author{
Gregor Jurak \\ University of Ljubljana, Slovenia \\ Wladimir Andreff \\ University of Paris, France \\ Stevo Popović \\ University of Montenegro, Nikšić, Montenegro \\ Damjan Jakšić \\ University of Novi Sad, Serbia \\ Jakob Bednarik \\ University of Ljubljana, Slovenia
}

\begin{abstract}
This paper examines the impact of the global economic crisis on revenues on all non-governmental sport organizations (sport NGOs) in Slovenia, as a small European economy. Five types of operating revenues of all sport NGOs from 2007 to 2010 have been analyzed. We found that the overall trend of sport NGOs revenues does not correspond exactly to the trends of the Slovenian economy. The greatest financial impacts were experienced in grassroots sport, while professional sport NGOs have increased their operating revenues, mostly due to increases of public revenues. The findings suggest that the true impact of the recession on Slovenian sport NGOs remains to be seen. We conclude that the ongoing recession will affect grassroots sport the least, while semi-professional and professional sport NGOs will be under financial threat. Because of the synergistic effects of different types of NGOs, this could affect the sustainability of Slovenian sport.
\end{abstract}

Keywords: grassroots sport, professional sport, sport club, revenue

Resumo - “O impacto da crise econômica global sobre as finanças de organizações desportivas não governamentais na Eslovénia está por ser visto." Este artigo analisa o impacto da crise econômica mundial sobre as receitas das organizações desportivas não governamentais (ONGs de esporte) na Eslovênia, como uma pequena economia europeia. Cinco tipos de receitas operacionais de todas as ONGs do esporte 2007-2010 foram analisados. Descobrimos que a tendência geral das receitas das ONGs do esporte não corresponde exatamente às tendências da economia eslovena. Os maiores impactos financeiros foram encontrados no esporte de base, enquanto as ONGs desportivas profissionais têm aumentado suas receitas operacionais principalmente devido ao aumento das receitas públicas. Os resultados sugerem que o verdadeiro impacto da recessão sobre as ONGs eslovenas desportivas continua a ser observado. Conclui-se que a recessão em curso afetará o esporte de base o mínimo, enquanto as ONGs de esportes semi-profissionais e profissionais estarão sob ameaça financeira. Por causa dos efeitos sinérgicos de diferentes tipos de ONGs isso poderá afetar a sustentabilidade do esporte esloveno.

Palavras-chave: esporte de base, esporte profissional, esporte amador, receita

Resumen- - "El impacto de la crisis económica mundial en las finanzas de las organizaciones deportivas no gubernamentales en Eslovenia queda por ver." Este artículo examina el impacto de la crisis económica global en los ingresos de las organizaciones deportivas no-gubernamentales (ONG's deportivas) en Eslovenia, como una pequeña economía europea. Han sido analizados cinco tipos de ingresos de explotación de todas las ONG’s deportivas desde 2007 a 2010. Encontramos que la tendencia general de los ingresos de las ONG's deportivas no se corresponden con la tendencia de la economía eslovenia. El mayor impacto financiero fue experimentado en el deporte base, mientras que las ONG's deportivas profesionales han incrementado sus ingresos de explotación, generalmente debido al incremento de ingresos 
públicos. Los hallazgos sugieren que el auténtico impacto de la recesión en las ONG’s deportivas eslovenias está aún por ver. Concluímos que la recesión en curso afectará lo mínimo al deporte base, mientras que las ONG’s deportivas semiprofesionales y profesionales estarán económicamente amenazadas. Debido a los efectos sinérgicos de los diferentes tipos de ONG, esto podría afectar la sostenibilidad de los deportes de Eslovenia.

Palabras clave: deporte base, deporte profesional, club deportivo, ingresos

\section{Introduction}

This study deals with the impact of the global financial crisis on operating revenues in non-governmental sports organizations (sports NGOs) in Slovenia as the small economy within the European Union (EU). ${ }^{1}$ Therefore, the first part of introduction provides an overview of the current global financial crisis and its effects on Slovenian economy. Further on impact of global crisis on global sport is presented. Then the authors discuss on the sports services market in Slovenia, and conclude this section by developing the main purpose of the study.

The financial market turmoil in 2007 and 2008 has led to the most severe financial crisis since the Great Depression (1929 to 1932) and threatens to have severe repercussions on the real economy (Brunnermeier, 2009). At the beginning in early 2007, the global economy entered a tumultuous period of contraction in real economic activity and disruption in financial markets. The global economy grew by $5.4 \%$ in 2007 and $2.8 \%$ in 2008 , while it declined by $0.7 \%$ in 2009 and grew again by $5.1 \%$ in 2010 (International Monetary Fund [IMF], 2011). Global financial conditions improved further in next two years, with global output growing by $3.9 \%$ in 2011 and $3.2 \%$ in 2012 (IMF, 2013). However, a broad set of indicators for global industrial production and trade suggests that growth did not strengthen further. At the same time, growth in advanced economies fell from $2.8 \%$ in 2007 to $-3.7 \%$ in 2009 , while it grew by $3.1 \%$ in 2010 , by $1.6 \%$ in 2011 and by $1.3 \%$ in 2012 . The outlook suggests a modest economic recovery for the period from 2013 to 2016 (IMF, 2013). As Slovenia's economy is highly dependent on foreign trade, mainly with other EU countries (Statistical Office of Republic of Slovenia [SORS], 2011), it has been also deeply affected by the global crisis.

Slovenia is a small open economy within the EU, with two million inhabitants and $€ 35,416$ million of gross domestic product (GDP) (SORS, 2011). It can be classified next to other small economies within EU with less than $€ 50$ billion GDP: Bulgaria, Estonia, Cyprus, Latvia, Lithuania, Luxemburg and Malta. Slovenia joined the EU in 2004 and has been portrayed as a success story among the so-called transition countries. After few years of uncertainty after its independence in 1991, the Slovenian economy constantly grew until the recent global economic crisis and became the richest of former communist countries with $\$ 25,939$ GDP per capita (IMF, 2012). In 2004, it entered $\mathrm{NATO}^{2}$ and the EU; in 2007, became the first former communist country

\footnotetext{
${ }^{1}$ The European Union (EU) is a unique economic and political partnership of 28 European countries that together cover much of the Europe continent.

${ }^{2}$ The North Atlantic Treaty Organization (NATO) is an intergovernmental military alliance of 28 member states across North America and Europe.
}

to join the Eurozone; in 2010, it joined the OECD. ${ }^{3}$ Affected by the global crisis, Slovenian GDP fell by close to $8 \%$ in 2009 , among the deepest declines in the OECD (OECD, 2011); GDP grew modestly in 2010 by $1.4 \%$, but fell again by $0.2 \%$ in 2011 (Eurostat, 2012). In August 2012, the three main ratings agencies all downgraded Slovenian sovereign debt as investors' voiced concerns that Slovenia would require a bailout. Moreover, it is extremely important to emphasize that Slovenia is within the Eurozone, which is considered to be a large downside risk from the global perspective (IMF, 2013). In particular, risks of prolonged stagnation in the Eurozone as a whole will rise if the momentum for reform is not maintained. If Slovenia rebalances its economy and restores competitiveness, its macro-economic performance should improve in coming years, but the improvement will most likely be smaller than the deterioration in the past period; real growth is expected in several years.

\section{Impact of global economic crisis on sport}

Although the crisis was triggered by the bursting of the housing bubble in the United States, forcing banks to write down several hundred billion dollars in bad loans caused by mortgage delinquencies, it has spread to all regions of the world with dire consequences for many industries. An overview of the globalization of the sport economy (Andreff, 2008, 2009; Andreff \& Andreff, 2009) confirms the main hypothesis of this study: the sport industry could not remain unaffected by these circumstances. Sport organizations have different organizational forms, operating methods, goals, and institutional characteristics than those in other sectors of the economy, so there is good reason to expect them to react differently to economic and financial downturns (Humphreys, 2010). Therefore, the global financial crisis presents significant challenges for the growth of the sport industry, representing a serious setback, because it is taking place at a time the sport business had begun to progress in economic performance.

There is a paucity of empirical studies analyzing this problem (Aughey, Danylchuk, \& Lebel, 2011; Coşkuner, Gacar, Çoban, \& Devecioğlu, 2011; Denhart, Villwock, \& Vedder, 2009; Devecioğlu, Cerrahoğlu, Çoban, \& Karademir, 2011; Peterman, \& Suntornpithug, 2013; Humphreys, 2010; Zimbalist, 2010), probably because of the short period since the global financial crises started. However, there are many reviewed analyses through case studies. Most empirical studies were done on professional sport, but not all of them have agreed that global financial crisis has caused an economic recession in this part of the sport industry. In the following, a short overview of the impact of the global crisis on sport

\footnotetext{
${ }^{3}$ The Organization for Economic Co-operation and Developmen
} $(\mathrm{OECD})$ is a global association of high-income developed countries. 
in North America and Europe is provided to portray a more comprehensive financial picture.

Humphreys (2010) has explored the effect of the recession and financial crisis that began in the middle of 2007 on five major professional sport leagues in North America. ${ }^{4} \mathrm{He}$ has concluded that attendance and franchise values declined slightly, and a few teams experienced financial problems; the nature of the sport product and institutional factors associated with the sport industry have, thus far, insulated professional sport from significant negative impacts. The evidence from this study suggested that attendance, a key source of revenues in professional sport leagues in North America, had responded to changes in the business cycle, implying that revenues from ticket sales and other game day revenue streams, like concessions and parking, may decline. The evidence indicated that the sales of premium seats and luxury suites might decline more significantly because the enterprises that buy these relatively expensive products have experienced sharp declines in revenues. According to the same author, television audiences, another key source of revenues for professional sport leagues, have not declined during the downturn as most of the revenues earned from broadcast rights come from long-term contracts that would not expire until 2012 or beyond. Moreover, the IEG survey (2009) has shown that North American companies were expected to increase their spending on sponsorship, including sport, by just $2.2 \%$ in 2009 ; this was the smallest increase in the 24 years that IEG had been tracking such spending. Generally, corporations were looking for ways to communicate their message to consumers while reducing their spending. Dramatic changes in the financial climate resulted in professional sport in North America experiencing mergers, team bankruptcies, athlete payroll purges, administrative staff reductions, and in some situations, even leagues going on lockout (Dillon, 2012; Humphreys, 2010; Sauter, 2013). A similar trend was experienced in university and college sport (Aughey, Danylchuk, \& Lebel, 2011; Denhart, Villwock, \& Vedder, 2009; Zimbalist, 2010). Because of decreases in corporate/alumni giving and significant drop-off rates in ticket sales and advertising revenue, fewer schools are fielding varsity programs and many have reduced scholarship funding. Budget crunches have forced early retirement packages, lay-offs and hiring freezes.

The situation is somewhat different in Europe. Club football, the most professionally managed and financially successful sport in Europe, faced its own financial crisis even before global economic crises (Andreff, 2007; Barajas \& Rodríguez, 2010; Lago, Simmons, \& Szymanski, 2006; Morrow, 2004). However, unlike professional sport in North America, European club football has not had declines in revenues thus far. The 'big five' European football leagues ${ }^{5}$ have shown admirable resilience to the economic climate in terms of revenue generation; nevertheless, the imbalance between revenue and costs has generally worsened (Deloitte, 2013). One notable exception is the German League (Bundesliga, 2013). Despite rising revenues, the European

\footnotetext{
${ }^{4}$ Major League Baseball (MLB), the National Football League (NFL), the National Basketball Association (NBA), the National Hockey League (NHL), and Major League Soccer (MLS).

${ }^{5}$ The English Premier League, Spanish La Liga, Italian Serie A, German Bundesliga and French Ligue 1.
}

football clubs reported record aggregate net losses of over $€ 1.6$ billion for 2010 (Deloitte, 2010). This prompted the Union of European Football Associations (UEFA) to propose the UEFA Financial Fair Play concept. However, Preuss, Schubert and Haugen (2012) have indicated that this concept may lead to unintended or even adverse effects. The prospects of European club football will be seen in coming years. However, study by Peterman and Suntornpithug (2013) shows that professional football itself could be resistant to crisis, since crisis doesn't affect match attendance of professional football in United Kingdom and United States.

The impact of economic crisis has been observed in some other areas of European sport. Unlike professional football clubs, other sport organizations generally have fewer opportunities for revenues from match-days, broadcasting, merchandising, trade of players and sponsorship; therefore, they are more dependent on other revenues. A small number of empirical studies indicate the negative impact of the global economic crisis on the non-professional sport sector in Europe.

Findings from Turkey (Coşkuner, Gacar, Çoban, \& Devecioğlu, 2011; Devecioğlu, Cerrahoğlu, Çoban, \& Karademir, 2011) show that the crisis deeply affected sport sponsorship revenues in 2009. This corresponds with a sharp fall of Turkey's GDP in the same year (Trading Economies, 2013). As sponsorship revenues are one of the most significant sources in Turkish sport, they had to take many saving measures to emerge from the crisis, and many sport federations had to reduce their activities or cancel some international tournaments, camp programs, and annual youth programs. In a study from Moldova, which reviewed the impact of the global financial crisis on public service delivery from 2008 to 2010, decreases of government and local finances for sport have been observed (Cainarean, Veverita, \& Veverita, 2011).

\section{Slovenian sport finances landscape}

The next issue to be discussed in this study is an overview of the sport services market in Slovenia, particularly concerning the revenues of sport organizations, since this is an important aspect of the global crises' impact on finances of sport NGOs.

Despite the country's unique characteristics, the model of financing sport organizations in Slovenia is remarkably similar to that used in the rest of the EU (Bednarik, Petrović, \& Šugman, 1998). The economic strength of Slovenian sport, expressed by the public and private expenditure on sport, increased from 1997 to 2007 , with average yearly growth of $26 \%$. Slovenian sport represents $1.93 \%$ to $2.3 \%$ of GDP $^{6}$ (Jurak, Bednarik, Kolenc, \& Kolar, 2010), which is similar to the macroeconomic effects of sport as in other developed countries (SpEA, 2012). Most funding (about $85 \%$ ) of Slovenian sport is secured from private sources, and the main source is households, with about $67 \%$ of all expenses for sport (Bednarik, Kolar, \& Jurak, 2010). This is connected with the fact that Slovenes are extremely active in sport, and they are good sport consumers. They are among the nations in the EU that are the most active in sport, closely following the Nordic countries (Eurobarometer, 2014), with

\footnotetext{
${ }^{6}$ This amount was $€ 598$ million in 2007.
} 
$78 \%$ of Slovenians being active in sport and $15 \%$ of them practicing sport on a regular basis (at least five times a week). ${ }^{7}$ The average Slovenian household spends $2.88 \%$ of the family budget on sport, equaling $€ 496$ per year (Bednarik et al., 2010). Twothirds of these funds are spent on sport products and one-third on sport services. High sport consumption, well-established physical education in schools (Hardman, 2002) and the entire organizational infrastructure of sport NGOs (Jurak et al., 2010) probably result in Slovenia being one of the most sporting successful countries at the biggest world sport competitions, with regards to income per capita and population (Humphreys, Maresova, \& Ruseski, 2012).

Despite its roots in a communist political system and consequently extensive public financing of sport in the past (pre1991), the share of public funding of Slovenian sport in recent decades has remained about 16\% (Bednarik et al., 2010). The level of public expenditure at both the national and local levels is lower than in most EU countries (Bednarik et al., 2010; Waelbroeck-Rocha et al., 2011).

Another valuable source of Slovenian sport should also be mentioned: volunteers. They represent almost $80 \%$ of the workers in sport NGOs. These volunteers perform $65.8 \%$ of all work in these organizations, and the estimated contribution of volunteer work to the revenues made by sport organizations is nearly $15 \%$. It is also estimated that volunteer work represents $13.5 \%$ of economic strength of sport outside the education system, equaling $€ 81.2$ million or $0.311 \%$ of GDP (Jurak et al., 2010). However, the amount of volunteer work lags behind that witnessed in other developed European countries (Waelbroeck-Rocha et al., 2011).

According to all the aforementioned, this study aims to investigate the likely impact of the global financial crisis on the finances of sport NGOs in Slovenia and to assess the extent to which that influence is reflected in certain groups of sport NGOs (it is assumed to exist).

\section{Methods}

The Slovenian sport services market has been monitored for more than fifteen years with the approach taken by Andreff and his colleagues (1994); therefore, high quality population data was used for this study. The survey examined operating revenues among all of 5,254 sport NGOs in Slovenia (sport clubs and associations) that provided annual income statements for each year from 2007 to 2010 . The data in this study has been obtained at the request of the authors, using annual financial reports from the Agency for Public Legal Records and Services in the Republic of Slovenia, the main primary source of official public and other information on business entities in Slovenia.

The operating revenues have been defined as a stream of benefits accruing to the sport NGOs from following types of revenues:

\footnotetext{
${ }^{7}$ The most practiced sport-recreational activities in Slovenia are walking, swimming, bicycling, alpine skiing, mountaineering, running, football, dance, fitness, badminton, basketball, gymnastics, aerobics, volleyball, inline roller skating and mountain biking.
}

Sales revenues (such as revenue from sport lessons, tickets sales, sponsorship contracts, media rights, merchandising, food and drink sales in the clubhouse, trade of players, the rental of premises, the organization of sport and non-sport events within the club's premises, tournament fees, own lotteries, etc.);

Public funds (include subsidies and grants from local authorities and government and revenues from licensed lotteries, gambling and betting operators channeled to the sport sector via a specialized institution in Slovenia: the Foundation for Sport);

Donations (revenues from individuals and companies without expectation of commercial return, as well as financial flows between sport associations and sport clubs);

Membership fees (an amount of money, i.e. a subscription, that it is paid regularly to be a member of a sport organization);

Other operating revenues (revaluation operating revenues that arise from the sale of items of property, equipment and of intangible assets as an excess of their sales value over their carrying amount and other operating revenues not reported elsewhere).

To obtain a more comprehensive insight, operating revenues were analyzed according to different types of sport NGOs. For this purpose, sport NGOs were divided into three groups of financial design types, according to a cluster analysis using Ward's hierarchical fusion algorithm clustering technique on 10 primary financial variables from the financial statements of sport NGOs: grassroots sport organizations, semi-professional and professional sport NGOs (Bednarik et al., 2013).

Basic descriptive characteristics were calculated for all variables regarding the revenues of all attained design types of sports NGOs, while Wilcoxon signed-rank test is used to examine a set of differences among all attained design types between 2007 and 2010. Finally, the comparisons were plotted as trend line diagram, while statistical significance was set at $p<0.05$. The analyses were carried out using Statistical Package for Social Sciences (SPSS) version 19.0 as well as R software environment for statistical computing and graphics which were also employed.

\section{Results}

The overall operating revenues of Slovenian sport NGOs rose by $8 \%$ from 2007 to 2010 and reached $€ 208.265$ million, however trend are different in three groups of the financial design types of sports NGOs (see Figure 1). Stagnation has been observed among revenues of grassroots sport organizations and semi-professional sport NGOs, while an increase has been observed in group of professional sport NGOs. The impact of professional and semi-professional sport NGOs on the overall operating revenues of Slovenian sport NGOs is much higher than their share in the total number of sport NGOs (Figure 2).

The operating revenues differ between groups of sport NGOs in level (see Table 1) as well as in their structure (see Figure 3).

Since operating revenues of sport NGOs are not normally distributed, the medians and interquartile ranges (IQR) of revenues of three different financial design types of sport NGOs, presented in Table 1, enable a more comprehensive 


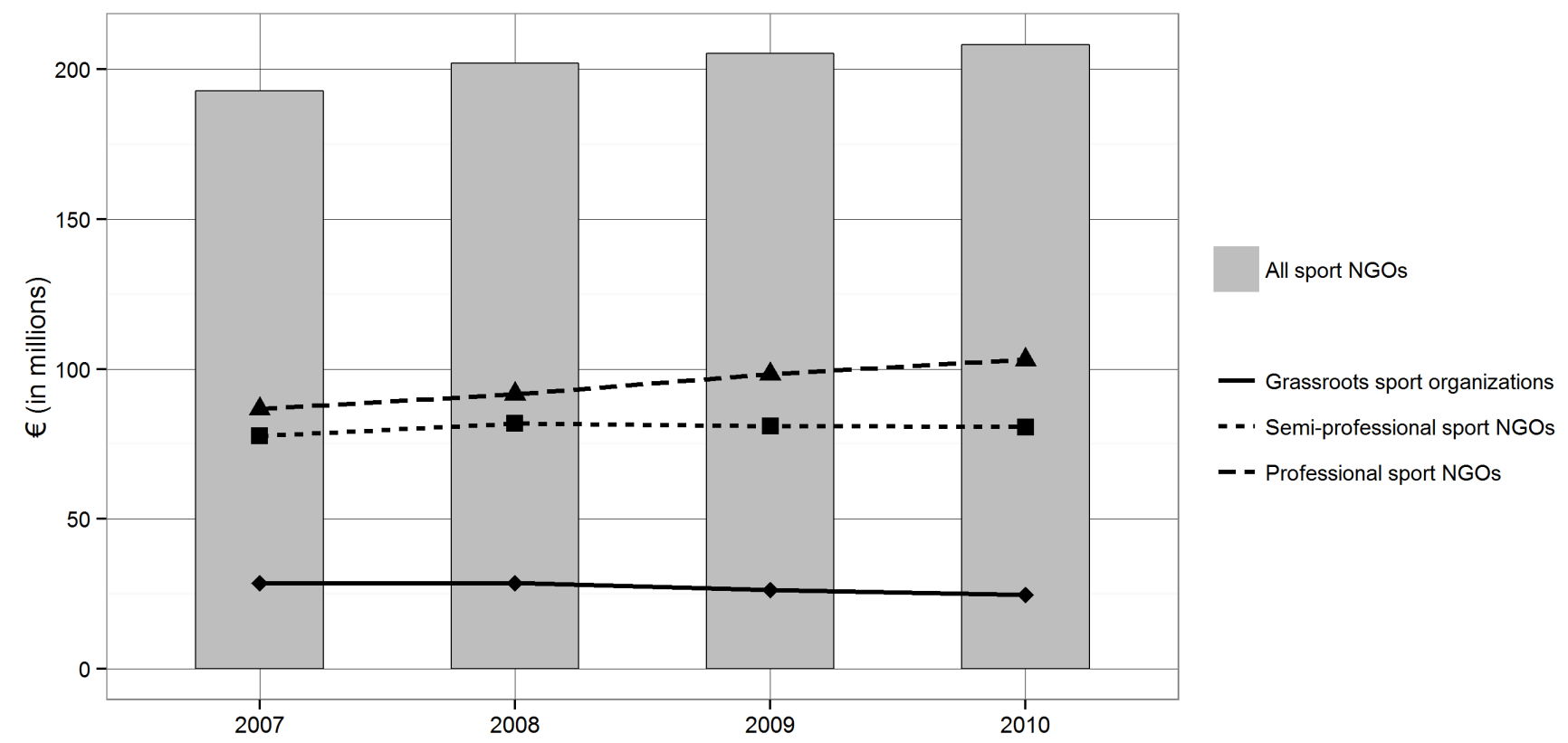

Figure 1. Trend lines of means of total operating revenues by financial design types of sport NGOs.

insight of trends. Generally, in semi-professional and professional sport NGOs the majority of operating revenues are significantly higher in 2010 than in 2007. The upward trend of operating revenues in the observed period was noted as being the greatest in group of professional sport NGOs. Their total operating revenues have been increased by $18 \%$, mostly because of increases of public revenues in 2009 and 2010. A positive trend can be also observed in semi-professional sport NGOs, which managed to maintain this trend with higher levels of all operating revenues. In contrast, in grassroots sport only public revenues are significantly higher in this period; consequently, their total operating revenues have decreased in last two years.

\section{Discussion}

This is the first study to analyze the impact of the global economic crises on an entire population of one group of sport organizations: on sport NGOs, in our case. What our study adds to previous knowledge about the impact of the global economic crises on sport is that until 2010 the impact of crises in some countries like it is Slovenia was relatively small and diverse regarding the different financial design types of sport NGOs. Our other finding leads to the assumption that Slovenia, as a small European sport economy, will encounter further serious consequences of global economic crises, and that the impacts of the crisis will be different for certain types of sport NGOs.

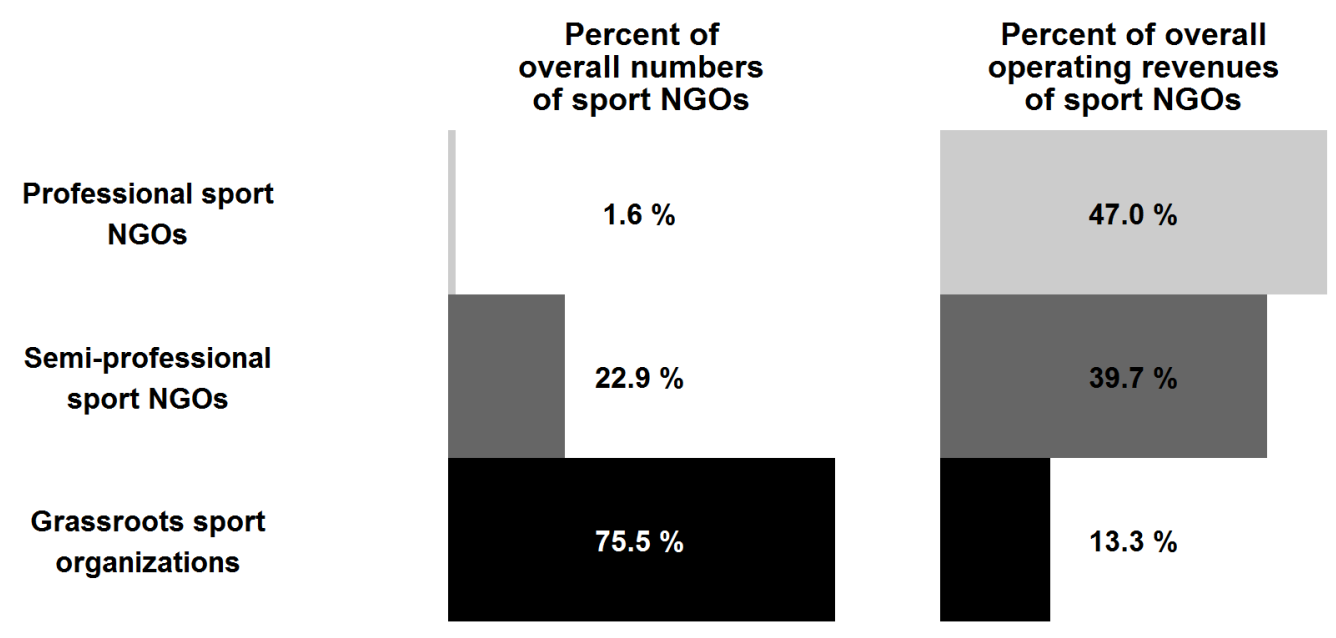

Figure 2. Share in overall operating revenues by three groups of sport NGOs. 
Table 1. Medians and interquartile range (IQR) of operating revenues of three different types of sport NGOs.

\begin{tabular}{|c|c|c|c|}
\hline & $\begin{array}{l}\text { Grassroots sport } \\
(n=3,969)\end{array}$ & $\begin{array}{l}\text { Semi-professional sport NGOs } \\
(n=1,202)\end{array}$ & $\begin{array}{l}\text { Professional sport NGOs } \\
(n=83)\end{array}$ \\
\hline \multicolumn{4}{|c|}{ Median [IQR] of Total operating revenues } \\
\hline 2007 & $3,096[997-7,733]$ & $31,408[15,050-66,324]$ & $523,318[262,066-1,298,673]$ \\
\hline 2008 & $3,173[1,001-8,390]$ & $35,380[16,446-72,474]$ & $550,490[295,340-1,250,733]$ \\
\hline 2009 & $2,990[900-7,834]$ & $34,673[16,856-72,830]$ & $523,097[307,199-1,157,609]$ \\
\hline 2010 & $2,801[788-7,496]$ & $36,550[18,354-75,807]$ & $619,014[304,863-1,283,679]$ \\
\hline Sig.* & $p=.00$ & $p=.00$ & $p=.00$ \\
\hline \multicolumn{4}{|c|}{ Median [IQR] of Public revenues } \\
\hline 2007 & $323[0-2,002]$ & $4,681[0-17,347]$ & $74,317[27,301-283,890]$ \\
\hline 2008 & $300[0-2,048]$ & $5,004.50[0-17,884]$ & $73,539[17,759-287,192]$ \\
\hline 2009 & $360[0-2,142]$ & $5,305[0-20,123]$ & $101,108[31,413-283,837]$ \\
\hline 2010 & $380[0-2,160]$ & $5,808.50[0-24,064]$ & $116,281[26,445-388,186]$ \\
\hline Sig.* & $p=.00$ & $p=.00$ & $p=.00$ \\
\hline \multicolumn{4}{|c|}{ Median [IQR] of Donations } \\
\hline 2007 & $100[0-1,290]$ & $2,782[0-10,957]$ & $7,816[200-43,104]$ \\
\hline 2008 & $114[0-1,250]$ & $3,703[300-12,297]$ & $8,286[353-45,206]$ \\
\hline 2009 & $13[0-940]$ & $3,167[300-9,883]$ & $10,056[1,930-30,487]$ \\
\hline 2010 & $0[0-795.50]$ & $4,126[398.50-10,734]$ & $7,150[1,050-26,811]$ \\
\hline Sig.* & $p=.00$ & $p=.05$ & $p=.80$ \\
\hline \multicolumn{4}{|c|}{ Median [IQR] of Membership fees } \\
\hline 2007 & $152[0-920]$ & $1,537[0-8,270]$ & $28,920[2,045-93,340]$ \\
\hline 2008 & $180[0-972]$ & $2,061[23.75-8,965]$ & $31,753[819-100,258]$ \\
\hline 2009 & $178[0-918]$ & $2,478[175-9,959]$ & $24,145[793-105,331]$ \\
\hline 2010 & $160[0-867]$ & $2,656[217.50-10,533]$ & $21,651[1,350-102,568]$ \\
\hline Sig.* & $p=.51$ & $p=.00$ & $p=.01$ \\
\hline \multicolumn{4}{|c|}{ Median [IQR] of Sales revenues } \\
\hline 2007 & $0[0-0]$ & $682[0-19,153]$ & $194,272[24,653-806,633]$ \\
\hline 2008 & $0[0-0]$ & $1,431[0-21,843]$ & $190,441[24,896-747,586]$ \\
\hline 2009 & $0[0-120]$ & $2,345[0-21,046]$ & $194,609[24,424-919,982]$ \\
\hline 2010 & $0[0-165]$ & $3,140[0-20,054]$ & $198,418[24,670-895,404]$ \\
\hline Sig.* & $p=.02$ & $p=.00$ & $p=.21$ \\
\hline \multicolumn{4}{|c|}{ Median [IQR] of Other operating revenues } \\
\hline 2007 & $0[0-0]$ & $0[0-389]$ & $0[0-11,270]$ \\
\hline 2008 & $0[0-0]$ & $0[0-1,017]$ & $118[0-13,515]$ \\
\hline 2009 & $0[0-0]$ & $0[0-1,294]$ & $851[0-12,350]$ \\
\hline 2010 & $0[0-0]$ & $0[0-1,176]$ & $1,184[0-15,626]$ \\
\hline Sig.* & $p=.00$ & $p=.10$ & $p=.83$ \\
\hline
\end{tabular}

* Wilcoxon test between 2007 and 2010

Structure of operating revenues of Slovenian sport NGOs

In the absolute sense, the overall operating revenues of Slovenian sport NGOs (already mentioned that was $€ 208.265$ million in 2010) are, for instance, equal to the budget of the Italian Football club Juventus (Deloitte, 2010), which is indicative of the financial strength of Slovenian NGOs. However, many of the accomplishments that were previously mentioned have been achieved with these limited finances. This leads to an assumption of the relative superior efficiency of the Slovenian model of sport. The different types of sport NGOs play an influential role in this model. Therefore, an analysis of the operating revenues of Slovenian sport NGOs was performed on three groups of sport NGOs, which have previously been clustered regarding to their financial characteristics (Bednarik et al., 2013). 


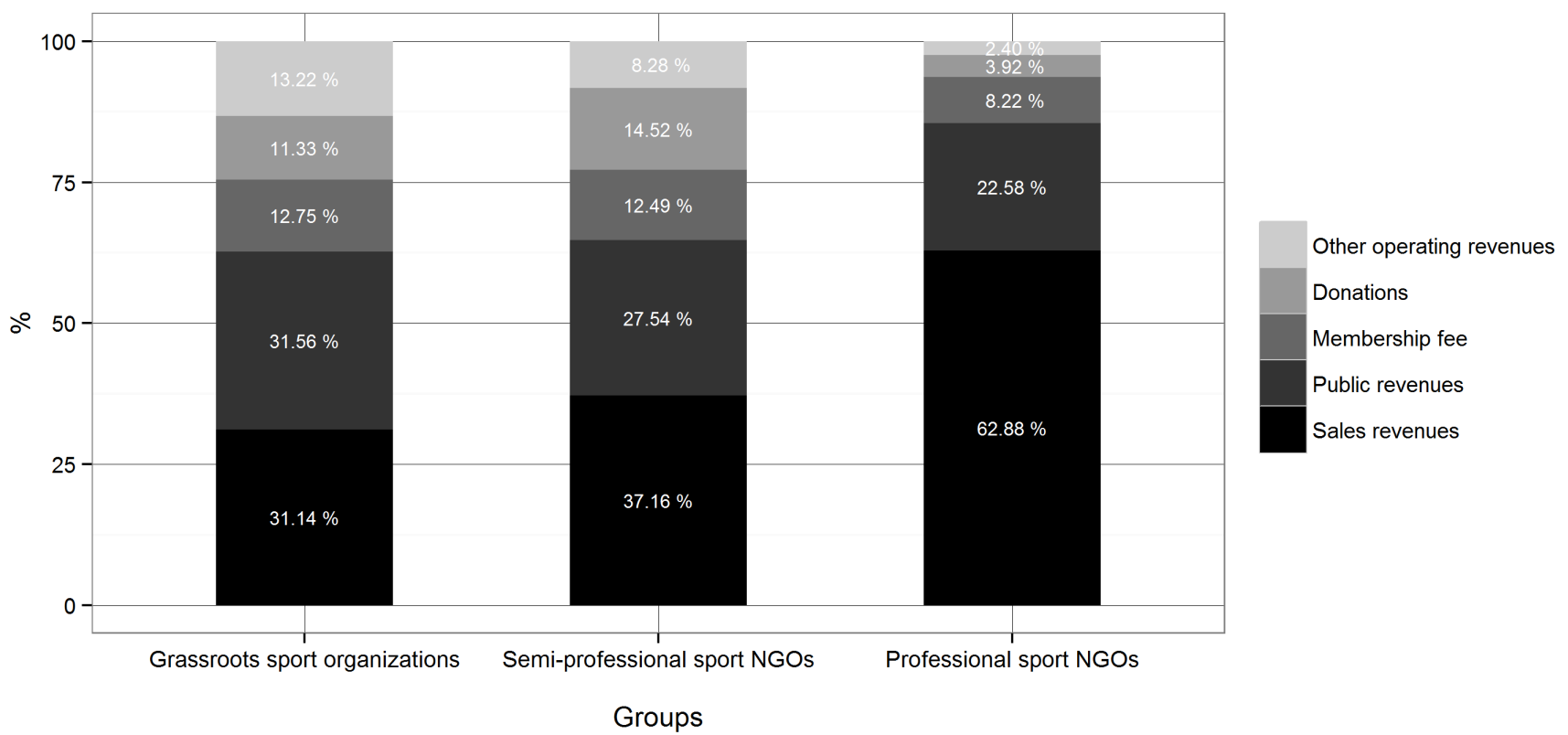

Figure 3. Structure of operating revenues in year 2010 by three groups of sport NGOs.

By number, the biggest group of Slovenian sport NGOs is grassroots sport organizations. These organizations have distinctly low total operating revenues (median around $€ 3,000$; see Table 1). Despite being in the very large majority ( $75.5 \%$ of all sport NGOs), these sport organizations account for merely $13.3 \%$ of the overall operating revenues of Slovenian sport NGOs (see Figure 2). Findings from Jurak, Bole Breznik and Bednarik (2009b) suggest that these are sport organizations that mainly carry out activities in order to satisfy the needs of their members. They are based exclusively on a voluntary basis (they do not have employed staff; however some work, especially coaching, is done by educated or qualified personnel under contract) and, therefore, consequently have fewer expenses and generate below-average revenues. However, regarding sport production at a national level, this is a particularly influential group since it represents the core of grassroots sport with a major impact on a public health (many people are involved in their programs since they represent, numerically, the biggest group of sport NGOs; see Figure 2) and strong value-added effects (much of the work in their programs are done by members themselves; Jurak et al., 2009b); the outcome is reached with limited finances. In the $\mathrm{EU}$, on average two thirds of the grassroots sport budgets are funded by the members themselves, through membership fees and other expenses, such as paid lessons; the share of public funding is $18 \%$ (Waelbroeck-Rocha et al., 2011). In Slovenian grassroots sport organizations, the share of members' funding is lower (see sum of membership fees and sales revenues in Figure 3 ), while the share of public financing is a little bit higher; $54 \%$ of all grassroots sport organizations in Slovenia have had public revenues (Bednarik et al., 2013), compared to the $61 \%$ reported by Waelbroeck-Rocha et al. (2011), meaning that in Slovenian grassroots sport public subsidies are allocated approximately the same way as the EU average.
The second largest group ( $22.9 \%$ of all NGOs) is the semi-professional sport NGOs, mostly national sport federations and larger sport clubs. These organizations have total average operating revenues around $€ 35,000$ (median; see Table 1), and they represent $39.7 \%$ of overall operating revenues of Slovenian NGOs (see Figure 2). Previous findings (Bednarik et al., 2013; Jurak et al., 2009b) suggest that this group differs from the first one in the professionalization of sport service processes. Sport organizations from this group have a unique position in the sport market, since they are extremely externally oriented in order to attract as many members as they can, mainly sportingly active users (this is visible in membership fees level of this group; see Table 1). Therefore, they have high levels of human resources, mainly contractors and volunteers, as well as a few professionals (Jurak et al., 2009b), who fulfill different organizational tasks (sport training, management, maintenance of sport facilities etc.).

The third smallest group ( $1.6 \%$ of all NGOs) is professional sport NGOs. This group is the one most covered in the media, i.e. the national sport federations and the biggest sport clubs from the most commercially interesting sports in Slovenia (football, skiing, basketball, handball, ice hockey; Jurak et al., 2009a, 2010). These organizations have total operating revenues around $€ 0.6$ million (median; see Table 1), and they represent $47 \%$ of the overall operating revenues of Slovenian NGOs (see Figure 2). This group also partly corresponds with previously found groups of sport NGOs in Slovenia (Jurak et al., 2009b). This type of sport organization is characterized by an above-average number of professional sport training and management personnel, and a large number of volunteers whose are predominately involved in organizing sport events. These sport organizations are mainly aimed at satisfying the needs for sport spectacles for passive sport consumers. They seem 
to have business strategies, market positions and infrastructure (organization, sport facilities) for developing their competitive advantages. However, substantial financial resources are needed in order to cover their expenses (Bednarik et al., 2013) and fulfill their ambitions in competitive sport. Among all sport NGOs, they are the most oriented toward sales revenues; therefore, they should operate more like enterprises. In this group, the biggest Slovenian NGO by the total operating revenues is the Football Association of Slovenia ( $€ 8.45$ million) and the sport club with the highest revenues is Maribor Football Club (€6.4 million). The level of these revenues can be compares with the budget of football teams in the $3^{\text {rd }}$ German league (Bundesliga, 2013); moreover, among EU small economies, a number of sport clubs have bigger budgets, such as APOEL Football Club from Cyprus, Levski Football Club from Bulgaria and Žalgiris Basketball Club from Lithuania. However, unlike the biggest Slovenian sport clubs, they have international sponsors, among the biggest are Gazprom, sponsoring Levski Football Club.

\section{Impact of the recession on operating revenues of Slovenian sport NGOs}

The comparison of operating revenues in the 2007-2010 period shows that sport NGOs in Slovenia have increased their overall operating revenues in comparison with the revenues before the global economic crisis started. Therefore, in spite of the crisis, in recent years the operating revenues of sport NGOs have continuously grown over the previous 10 years (Bednarik et al., 2010; Jurak et al., 2010). This does not correspond exactly to the trends of Slovenian economy in the 2007-2010 period (OECD, 2011). A more detailed analysis reveals important differences in operating revenues regarding the three groups of sport NGOs and explains revenue fluctuations. To explain trends, one should understand the meaning of certain types of operating revenues in the observed sport organizations.

In grassroots sport organizations, sales revenues are represented mostly by fees for exercise programs and sport courses, but in professional sport NGOs most sales revenues are generated by sponsorship, ticket revenues, trade of athletes and media rights, while in semi-professional sport NGOs they are mixed. Similar structures of revenues of grassroots sport (Waelbroeck-Rocha et al., 2011) and professional sport (Deloitte, 2013) have been found in other studies. Therefore, sales revenues in grassroots sport organizations are more influenced by household expenditure and their purchasing power. Purchasing power in Slovenia dropped in the 2008-2010 period by $8.3 \%$ (Eurostat, 2012), which is in line with the stagnation of operating revenues in grassroots sport.

However, sales revenues of professional sport NGOs are more influenced by the interests of enterprises and their capability for financing of sport and their marketing activities. In contrast to some bigger sport economies, the Slovenian sport sponsorship market has been characterized by social networks (Jurak, Bednarik, \& Kovač, 2009a). The management of enterprises considers sport sponsorship to be a social vehicle for introducing the company name into the media or for creating new acquaintances with other sponsors/business partners and politicians at sport events, thus widening the network of their business/social connections. The biggest sport clubs and the biggest national sport federations have been mainly sponsored by government-owned enterprises. Sponsors from abroad are very rare. Therefore, it can be assumed that professional sport NGOs expanded their sponsorship revenues more on the basis of socio-political than marketing interests. Since the size of Slovenian market is two million people and the fact that the sales of media rights in other countries are not large due to a lack of interest in Slovenian competitions, there is also limited potential for sponsors and advertisers for the broadcasting of sport events. During the economic crisis, one possible strategy for existing sponsors is changing their priorities in favor of the most media-exposed sports, athletes, clubs and events. We do not have separate data for sponsorship revenues and are thus unable to analyze this problem more thoroughly. However, since sales revenues of professional sport NGOs did not change in the 2007-2010 period (see Table 1), we assume redistribution of sponsorship revenues within professional sport NGOs is occurring.

Public revenues are represented by subsidies and grants at national, regional or local levels. In Slovenia, about $75 \%$ of public revenues comes from local authorities (Jurak et al., 2010), which is main source of public finances of grassroots sport. Government finances are concentrated on national sport federations. Therefore, the large increase of public revenues in professional sport NGOs in 2009 and 2010 (see Table 1) is mostly a consequence of much higher financing of sport federations on the government level caused by political decisions and some change of criteria that were initiated by national sport federations at the start of the global financial crises.

A donation in context of revenues of sport NGOs is revenue given by individuals or legal entities for sport organization activities without an expectation of a commercial return (unlike sponsorship). Moreover, these are payments made by the sport federations to the clubs for some of their programs. Therefore, it is logical that donations represent more important revenues in grassroots sport organizations than in professional sport NGOs (see Figure 3, structure of revenues). With the beginning of the global economic crisis, donations have been decreased particularly in grassroots sport; so much so that the median has fallen to zero (see Table 1). According to a recent study on the sport participation of Slovenians, which shows stable trends (Eurobarometer, 2014), it appears that this did not affect participation in grassroots sport.

A membership fee is charged as part of being an NGO's member. In return, the member has membership rights (access to sport facilities and programs, candidature for NGO' bodies, voting etc.). In the structure of finances, membership fees represent highly significant revenue in grassroots sport organizations and semi-professional sport NGOs, but less important revenue in professional sport NGOs (see Figure 3). A trend of decreasing revenue from membership fees can be observed in grassroots sport and professional sport NGOs, while an increasing trend in semi-professional sport NGOs is present (see Table 1).

The observed trend of the operating revenues of sport NGOs reflects the economic situation in Slovenia in the observed period. However, in 2011 and 2012, the Slovenian GDP fell again and the Slovenian economy is currently faced 
with risks of prolonged stagnation. The OECD (2012) has predicted reductions of Slovenian GDP by $2.4 \%$ in 2012 and $1.1 \%$ in 2013 . Rising fiscal deficits and public debt have already required stabilization (austerity) policies in Slovenia. Despite a recent paper by IMF economists Blanchard and Leigh (2013) criticizing policies of slashing budgets too rapidly early in the euro crisis, starving many economies of much-needed growth; the Slovenian government is determined to take this route. Along with the strained economic situation and its reflection on sport finances, we believe this would greatly affect the finances of Slovenian sport, but differently according to type of sport NGOs.

It seems that grassroots sport organizations will suffer the least in these new circumstances, as they have the most balanced structure of revenues, a stable trend of revenues and a structure of expenses that enables the easiest adjustments (Bednarik et al., 2013). In this group, a severe decline of all revenues, with exception of membership fees can be expected, as these organizations are mostly fulfilling interests of small number of members, who will continue to pay the fees at the same level. A gradual slightly negative trend of revenues of these organizations has already been observed in recent years; therefore, an additional decrease will not represent major disruptions for these organizations. Supporting this statement are the facts that these organizations generally do not have problems with liquidity and solvency, and they can very quickly adjust their expenditure with the revenues, as their budgets include only a small proportion of fixed costs, such as the salaries of employees (Bednarik et al., 2013).

Semi-professional sport NGOs will experience larger financial difficulties. They are mostly dependent on the revenues from households (membership fees, training fees and entrance tickets), as their programs are particularly aimed at these groups. Smaller purchasing power (Eurostat, 2012), more difficult business conditions and austerity measures in public finances (IMF, 2013; OECD, 2012) will result in decreases of all revenues of these organizations. As these sport NGOs have more fixed costs (employees) in their budgets than the grassroots sport organizations do (Bednarik et al., 2013), they will also have more difficulties in adjusting their expenditure to the decrease in revenues.

The largest problems can be expected in professional sport NGOs. These organizations depend on sales revenues the most and are thus greatly influenced by the economic situation; at the same time, they experienced a considerably unstable positive trend in revenues from the public funds at the start of recession.

Due to limitations in data collection, a more thorough analysis of sales revenues regarding the different types of these revenues (sponsorship, media rights, ticket sales, players' trade etc.) is impossible. Some information about changes of the structure of these revenues from business reports of certain professional sport NGOs indicates a rapid fall of sponsorship revenues in 2011 and 2012. Excessive emphasis on sponsorship revenues can therefore represent a threat for these organizations.

Significantly increased public financing of professional sport NGOs in 2009 and 2010 has caused so-called financial doping. ${ }^{8}$ In these years, the programs of national sport governing bodies have experienced particularly large financing from the government funds, which resulted in increased expenditure. It can be assumed that (with a few exceptions) these sport NGOs did not adjust their business models to changed circumstances in the economic market due to experiencing total positive trend of business income. As a result, in coming years these sport NGOs will be ill-prepared for changes, as the public financing of their programs will sharply decline. This decline will also correspond with a decline in sponsorship revenues, which represents an important part of their sales revenues. If these organizations wish to balance their expenditures with revenues, they will quickly have to enact considerable cuts in salary expenses and/or dismiss their staff. Nevertheless, it is more likely that they will merely postpone the payments and prolong the agony. This will be particularly true for sport clubs in professional competitive sport, where the costs of professional teams represent more than half of all the budget expenses. Even larger problems will be experienced by the NGOs, which are highly leveraged and have intense liquidity and solvency problems. According to findings of Bednarik et al. (2013), 35\% of professional sport NGOs is operating under net losses from previous years.

The opinion of the authors of this paper is that the sport NGO sector in Slovenia will be faced with de-professionalization, which had already been predicted prior to the beginning of the crisis (Jurak et al., 2010). This process will strongly affect many semi-professional and professional sport NGOs. At the moment, these two groups employ significant numbers of university-educated coaching staff, supported through the system of public financing and enabling them stable running. Austerity measures will also affect such financing, and without suitable business solutions these sport NGOs will not be able to finance the employees from other sources. Consequently, unpaid bills, dismissals and staff resignations will follow, resulting in destabilization of functioning of the sport NGOs.

We assume that the consequences will be even greater in professional sport NGOs because they employ more professional staff. A demise of some professional teams and their return to amateur status can be expected. Only professional sport NGOs with proper business strategies regarding their resources (sport facilities, media attention, people involved, etc.) can survive the recession with the same model as before crisis. Generally speaking, their business models better resemble the functioning of business companies rather than that of NGOs. Some sport NGOs have already set up such models; however, time will tell how successful they are. For example, the Slovenian skiing association has transferred the majority of the financial burden of the national teams onto the competitors and their families. Maribor Football Club has changed its income structure, with a significant increase of revenues from the transfers of players.

\footnotetext{
${ }^{8}$ The situation in which a government financed professional sport NGOs heavily, in order to ensure continuous growth of total revenues, jeopardizing their long-term financial future if they will rely too heavily on public finances rather than generating their own (sales revenues).
} 
The next important question is when it can be expected that the status of operational revenues in semi-professional and professional sport NGOs will again reach the level prior to the economic crisis? It seems such a recovery will take some time and will happen only if these sport NGOs will change their business models. To be specific: the majority of current models of professional sport in Slovenia are obsolete. This will be most apparent with regard to one of the larger sources of revenue in these organizations, i.e. sponsorship, as the sponsorship market in Slovenia will never be return to the state it was before the economic crisis. The model of sponsorship in Slovenian sport has been based on social-political connections with mainly state -owned companies; recently passed legislation on the Slovenian Sovereign Holding will result in a sale of state shares in a large number of these companies. As a result, the withdrawal of the state from the economy will presumably result in more deliberate decisions of companies for sponsoring of all types of activities, including sport. Marketing interest in particular sports will become particularly important, which will enable companies to fulfill their marketing goals. If Slovenian and perhaps even foreign companies will recognize Slovenian sport as a tool for fulfilling their marketing goals, then the Slovenian sport could, as a result of global trends (IEG, 2013), increase sponsorship revenues; otherwise, the money will be directed elsewhere.

A considerable threat to the stability of the future functioning of semi-professional and professional sport NGOs will also be the dependency on public finances, particularly in national governing bodies. Specifically, the majority of them are already excessively dependent on state resources (Jurak et al., 2010).

\section{Measures for sport NGOs to address the prolonged recession}

According to the forecast of recession's impact on European sport (W. Andreff, 2009) and economic forecast and socio-political circumstances in Slovenia, we believe the true measure of economic turmoil will be seen over next few years. It is vital for Slovenian sport NGOs to survive recession, not merely for this sector itself, but also because of its impact on public health and economic growth. In Slovenia, the public health benefits associated with the regular practice of sport have not yet been analyzed; however, various studies from developed countries (Cadilhac et al., 2011; Katzmarzyk \& Janssen, 2004; Scarborough et al., 2011) have quantified the reduced health care and other costs to society of a regular practice of sport. These studies show that the average annual health care costs for physically inactive persons are about $30 \%$ higher than for physically active people, which could be amount to between $€ 250$ and $€ 1,200$ of benefits of a regular practice of sport per person per year. Slovenian sport NGOs also play an important part of economic growth. A recent study of SportsEconAustria (SpEA, 2012) on the contribution of sport to economic growth and employment in the EU has shown that the share of sport-related value added and the share of sport-related employment for Slovenia is high above the EU average.

We believe that grassroots sport will survive the financial crisis almost unchanged in its way of business. However, it is very important for the sustainability of Slovenian sport as whole to keep different types of sport NGOs well-functioning, because of their synergistic effects on Slovenian sport success. Therefore, it is crucial for semi-professional and professional sport NGOs to be better equipped to deal with recession. Each sport NGO must to find each own combination of measures regarding to their resources and opportunities.

One possible course is to enhance domestic expenditure for sport by raising the revenues generated from households, combined with the more efficient exploration of given resources within Slovenian sport. Raising the household expenditure for sport services implies many measures (see Waelbroeck-Rocha et al., 2011), which require the development of sport NGOs' services for existing and new target groups of consumers. However, for high level and professional sport organizations, identification with the sport organization seems to be the ultimate key. When it comes to the internal market of sport, strategic partnerships between sport organizations must be mentioned. Instead of focusing on yields alone, professional and high level sport organizations could be based on a special combination of competition interest and sport responsibility, which is grounded in utilizing the synergies that exist between sport clubs within the same sport discipline. Only few sport clubs in Slovenia compete in high-level commercial sport competitions (i.e. Football Club Maribor, Basketball Club Olimpija, Basketball Club Krka, Ice hockey Club Olimpija, ACH Volley), have a brand that attracts major sponsors (i.e. Olimpija) and modern sport facilities (i.e. Stožice Arena, Ljudski vrt Football Stadium). These organizations could make a network of partnerships with domestic sport clubs to help them organize youth teams (with professional support, management, sport facilities and premises), train talents and then fairly trade for them. This could share limited finances with all partners.

Regardless, semi-professional and professional sport NGOs should also perform cost-saving measures, requiring these NGOs to prepare a specific action plan in order to best exploit the opportunities available. The highest expenditures of these sport NGOs are for costs of services (Bednarik et al., 2013), among which are contract personnel payments, leasing sport facilities and various charges for competitions. Reductions of personnel payments should be achieved mostly through the reviewing of player salaries, and less by lay-offs of permanent professional staff, which are capable of providing sport services of high quality. New, more economically realistic and sustainable bases of payments should be set. Regarding charges for sport premises, new contract terms with local communities (which are mainly their owners) should be made. Cost reductions in the competition system should be designed together with sport federation and other sport clubs, with possible measures as fewer games/competitions performed, rules adaptations in minor leagues to avoid some costs (e.g. few referees, shortening of competition time) and reduction of work and cost of competition bureaucracy. National sport federations could reduce the costs of national teams by carrying out all of the sport training programs in suitable sport facilities in Slovenia.

There are limitations to our study, and care should be taken in generalizing it to different countries, since there are considerable 
differences in the economic situation even among small EU economies. The study was done with population data; however, it was limited to data from income statements of sport NGOs. These data did not allow as much of an analytical approach as in some types of operating revenues. With the income statements, we were also unable to gather the information about some important outputs of sport NGOs, such as the power of volunteers, who are an important resource of Slovenian sport and could be affected by global economic crises, as has been shown by the negative trend of the prevalence of volunteering in Slovenian sport (Eurobarometer, 2014).

\section{References}

Andreff, M., \& Andreff, W. (2009). Global Trade in Sports Goods: International Specialisation of Major Trading Countries. European Sport Management Quarterly, 9(3), 259-294.

Andreff, W. (2007). French Football A Financial Crisis Rooted in Weak Governance. Journal of Sports Economics, 8(6), 652-661.

Andreff, W. (2008). Globalization of the Sports Economy. Rivista di Diritto ed Economia dello Sport, 4(3), 13-32.

Andreff, W. (2009, June). Public and private sport financing in Europe: the impact of financial crisis. Paper presented at the $84^{\text {th }}$ Western Economic Association International Conference, Vancouver.

Andreff, W., Bourg, J.-F., \& Halba, B. (Eds.) (1994). The economic importance of sport in Europe: financing and economic impact. Brussels: Committee for Development of Sport of the Council of Europe.

Aughey, T., Danylchuk, K., \& Lebel, K. (2011). The impact of the economic recession on Canadian Interuniversity Sport (CIS) programs. Journal of Intercollegiate Sport, 4(1), 147-157.

Barajas, A., \& Rodríguez, P. (2010). Spanish football clubs' finances: crisis and player salaries. International Journal of Sport Finance, 5(1), 52-66.

Bednarik, J., Andreff, W., Popović, S., Jakšić, D., Kolar, E., \& Jurak, G. (2013). Financial taxonomy of non-governmental sports organizations. Kinesiology, 45(2), 241-251.

Bednarik, J., Kolar, E., \& Jurak, G. (2010). Analysis of the sports services market in Slovenia. Kinesiology, 42(2), 142-152.

Bednarik, J., Petrović, K., \& Šugman, R. (1998). Funding of Slovenian sport during transition. Kinesiologia Slovenica, 4(1), 12-16.

Blanchard, O., \& Leigh, D. (2013). Growth Forecast Errors and Fiscal Multipliers. IMF Working Paper. Retrieved April 5, 2013, from International Monetary Fund Web site: http://www.imf.org/ external/pubs/ft/wp/2013/wp1301.pdf

Brunnermeier, M. K. (2009). Deciphering the liquidity and credit crunch 2007-2008. Journal of Economic Perspectives, 23(1), 77-100.

Bundesliga (2013). The Bundesliga report 2013. Retrieved April 15, 2013, from http://www.bundesliga.com/en/medien/report/index.php

Cadilhac, D. A., Cumming, T. B., Sheppard, L., Pearce, D. C., Carter, R., \& Magnus, A. (2011). The economic benefits of reducing physical inactivity: an Australian example. International journal of behavioral nutrition and physical activity, 8(1), 99.

Cainarean, N., Veverita, E., \& Veverita, P. (2011). The impact of the global financial crisis on education and healthcare in the economies of the former Soviet Union - the case of Moldova. Warsaw: Center for Social and Economic Research.

Coşkuner, Z., Gacar, A., Çoban, B., \& Devecioğlu, S. (2011). The effect of crisis of global economic to sport sponsorship in Turkey. Paper presented at the XIII IASE and III ESEA Conferences on Sports Economics. Retrieved November 5, 2012, from http://www. sporteconomicsprague.cz/presentations.htm
Deloitte (2010). Football Money League 2010. Retrieved December 14, 2012, from http://www.deloitte.com/assets/Dcom-Ecuador/ Local\%20Assets/Documents/Estudios/100412-ec_DeloitteFML2010.pdf

Deloitte (2013). Football Money League 2013. Retrieved April 5, 2013, from http://www.deloitte.com/view/en_GB/uk/industries/sportsbusinessgroup/sports/football/deloitte-football-money-league/

Denhart, M., Villwock, R., \& Vedder, R. (2009). The academics athletic trade-off. Universities and intercollegiate athletics. Retrieved February 15, 2013, from Center for College Affordability and Productivity Web site http://www.centerforcollegeaffordability. org/uploads/athletics.pdf

Devecioğlu, S., Cerrahoğlu, N., Çoban, B., \& Karademir, T. (2011). Effects of global economic crisis on Turkish sports sector. Paper presented at the XIII IASE and III ESEA Conferences on Sports Economics. Retrieved November 5, 2012, from http://www.sporteconomicsprague.cz/presentations.htm

Dillon, J. (2012). Major League Baseball Team Bankruptcies: Who Wins? Who Loses? Loyola of Los Angeles Entertainment Law Review, 32(3), 297-333.

Eurobarometer (2014). Eurobarometer Sport and Physical Activity. Retrieved April 25, 2014, from http://ec.europa.eu/public_opinion/ archives/ebs/ebs_412_en.pdf

Eurostat (2012). National accounts. Retrieved October 10, 2012, from http://epp.eurostat.ec.europa.eu/portal/page/portal/national_accounts/introduction

Hardman, K. (2002). European physical education/sport survey. Reports of summary of findings. Strasbourg: Council of Europe.

Humphreys, B. (2010). The Impact of the Global Financial Crisis on Sport in North America. Optimal strategies in sports economics and management. In S. Butenko, J. Gil-Lafuente \& P. Pardalos (Eds.), Optimal Strategies in Sports Economics and Management (pp. 39-57). Berlin Heidelberg: Springer.

Humphreys, B., Maresova, K., \& Ruseski, J. (2012). Institutional factors, sport policy, and individual sport participation: an international comparison. Retrieved December 28, 2012, from http:// econpapers.repec.org/paper/risalbaec/2012_5f001.htm

IEG (2009). Decision-makers survey: sponsors favor activation budgets in 2009. Retrieved 1.10.2010, from http://www.sponsorship.com/ IEGSR/Topics.aspx? categoryid=1149

IEG (2013). 2013 sponsorship outlook: spending increase is double-edged sword. Retrieved from http://www.sponsorship.com/ IEGSR/2013/01/07/2013-Sponsorship-Outlook--Spending-Increase-Is-Dou.aspx

IMF (2011). World economic outlook: slowing growth, rising risks. Retrieved June 20, 2012 from http://www.imf.org/external/pubs/ $\mathrm{ft} /$ weo/2011/02/pdf/text.pdf

IMF (2012). World Economic Outlook Databases. Retrieved January 20, 2013 from http://www.imf.org/external/ns/cs.aspx?id=28

IMF (2013). Modest growth pickup in 2013, projects IMF. Retrieved April 2, 2013 from http://www.imf.org/external/pubs/ft/survey/ so/2013/NEW012313A.htm

Jurak, G., Bednarik, J., Kolenc, M., \& Kolar, E. (2010). Analiza ekonomskih učinkov športa v Republiki Sloveniji. In E. Kolar, G. Jurak \& M. Kovač (Eds.), Analiza nacionalnega programa športa $v$ Republiki Sloveniji 2000-2010 [Analyses of National programme of sport in Republic of Slovenia 2000-2010] (pp. 61-82). Ljubljana: Faculty of Sport.

Jurak, G., Bednarik, J., \& Kovač, M. (2009a). The sponsorship potential of Slovenian sport Acta Universitatis Carolinae. Kinanthropologica, 45(1), 95-113.

Jurak, G., Bole Breznik, M., \& Bednarik, J. (2009b). Razvrstitev slovenskih športnih organizacij glede na nekatere njihove značilnosti 
[Classification of Slovenian sports organisations according to their characteristics], Šport, 57(1/2), 56-61.

Katzmarzyk, P. T., \& Janssen, I. (2004). The economic costs associated with physical inactivity and obesity in Canada: an update. Can J Appl Physiol, 29(1), 90-115.

Lago, U., Simmons, R., \& Szymanski, S. (2006). The financial crisis in European football: an introduction. Journal of Sports Economics, 7(1), 3-12.

Morrow, S. (2004). The financial crisis in Scottish football. Scottish Affairs, 48-57. Retrieved January 15, 2013 from http://www.scottishaffairs.org/backiss/pdfs/sa47/sa47_Morrow.pdf

OECD (2011). OECD Economic Surveys Slovenia. Retrieved September 15, 2012 from http://www.oecd.org/eco/47103634.pdf

OECD (2012). Economic outlook, analysis and forecasts. Slovenia Economic forecast summary (November 2012). Retrieved February 10, 2013 from http://www.oecd.org/eco/economicoutlookanalysisandforecasts/sloveniaeconomicforecastsummary.htm

Peterman, R., \& Suntornpithug, N. (2013). Investigating the impact of economic uncertainties on attendance of Premier League Soccer in the United Kingdom and Major League Soccer in the United States. Journal of Applied Business and Economics, 14(3), 16-23.

Preuss, H., Schubert, M., \& Haugen, K. (2012). UEFA financial fair play: the curse of regulation. Retrieved February 10, 2013 from http://www.sport.uni-mainz.de/Preuss/Download\%20public/ Working\%20Paper\%20Series/Working_Paper_No_7_UEFA_Financial_Fair_Play-The_Curse_of_Regulation.pdf

Sauter, M.B. (2013). Seven Professional Sports Teams on the Brink of Collapse. Retrieved on April 25, 2014, from http://www.huffingtonpost.com/2011/11/08/bankrupt-sports-teams-seven-collapse247-wall-st_n_1082548.html.

Scarborough, P., Bhatnagar, P., Wickramasinghe, K. K., Allender, S., Foster, C., \& Rayner, M. (2011). The economic burden of ill health due to diet, physical inactivity, smoking, alcohol and obesity in the UK: an update to 2006-07 NHS costs. J Public Health, 33(4), 527-535. doi: 10.1093/pubmed/fdr033

SORS (2011). Slovenia in Figures 2011. Retrieved December 10, 2012 from http://www.stat.si/doc/pub/slo_figures_11.pdf

SpEA (2012). Study on the Contribution of Sport to Economic Growth and Employment in the EU. Brussels and Vienna: SportsEconAustria.

Trading Economies (2013). Turkey GDP Growth Rate. Retrieved February 12, 2013, from http://www.tradingeconomics.com/turkey/gdp-growth

Waelbroeck-Rocha, E., Avice, E., Nguyen, T. A., Mirgon, C., Lourimi, S., Mialet, G., ... Montel, J. (2011). Study on the funding of grassroots sports in the EU. With a focus on the internal market aspects concerning legislative frameworks and systems of financing. Brussels: Eurostrategies.
Zimbalist, A. (2010). Dollar dilemmas during the downturn: a financial crossroads for college sports. Jornal of Intercollegiate Sport, 3(1), 111-124.

\section{Authors' note}

Gregor Jurak and Jakob Bednarik are affiliated with the Faculty of Sport, University of Ljubljana, Ljubljana, Slovenia.

Wladimir Andreff is affiliated with the Centre d'Economie de la Sorbonne, University Paris 1, Pantheon Sorbonne, Paris, France.

Stevo Popović is affiliated with the Faculty for Sport and Physical Education, University of Montenegro, Nikšić, Montenegro.

Damjan Jakšić is affiliated with the Faculty of Sport and Physical Education, University of Novi Sad, Novi Sad, Serbia.

\section{Corresponding author}

Gregor Jurak

University of Ljubljana

Faculty of Sport

Gortanova 22, 1000 Ljubljana, Slovenia

Telephone: 0038615207783

Fax: 0038615207750

E-mail: gregor.jurak@fsp.uni-lj.si

Manuscript received on November 16, 2013

Manuscript accepted on April 23, 2014

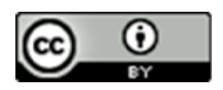

Motriz. The Journal of Physical Education. UNESP. Rio Claro, SP, Brazil - eISSN: 1980-6574 - under a license Creative Commons - Version 3.0 